\title{
Earthquakes in Kashgar
}

\section{Author(s): George Macartney}

Source: The Geographical Journal, Vol. 20, No. 4 (Oct., 1902), pp. 463-464

Published by: geographicalj

Stable URL: http://www.jstor.org/stable/1775581

Accessed: 24-06-2016 20:02 UTC

\section{Your use of the JSTOR archive indicates your acceptance of the Terms \& Conditions of Use, available at}

http://about.jstor.org/terms

JSTOR is a not-for-profit service that helps scholars, researchers, and students discover, use, and build upon a wide range of content in a trusted digital archive. We use information technology and tools to increase productivity and facilitate new forms of scholarship. For more information about JSTOR, please contact support@jstor.org.

The Royal Geographical Society (with the Institute of British Geographers), Wiley are collaborating with JSTOR to digitize, preserve and extend access to The Geographical Journal 
The Shwe-li or Lung Kiang rises north-east of tie Tai-ping, and very probably not more than 5 to 10 milcs north. Above the Tali-fu-Yung-chang-Teng-yueh road it is hemmed into a very narrow valley, and has no tributaries to speak of. The area it drains south of the abore point increases considerably, and as it joins the Irawadi below Katha, and just about opposite to Tig-yaing, the Tai-pi-no (so often erroneously called the Tai-ping), on the contrary, is joined by quite considerable streams within the first 20 miles or so of the river, and drains quite a considerable area compared to the Shwe-li in its (the Shwe-li's) upper reaches; hence the difference in quantity of water notcd by ycu. Another point, too, is that the rainfall decreases towards the east of the Irawadi watershed and the outlying spur which separates the Shwe-li basin from the Salwen, and, indeed, the whole country east of Tai-ping, owing to long-continued deforestation and general barrenness of the soil, for many a long year had a much smaller yearly rainfall than that which falls $i_{n}$ the Irawadi basin. This, too, would conduce to the less volume of water carried down by the Shwe-li in its upper reaches. As, however, it flows into the Irawadi basin proper, and receives the drainage of the part of the lower hills of the north Shan States round south of Bhamo, its volume increases rapidly in the rainssends down an enormous volume of water into the Irawadi (I have seen the Shweli in flood).

This information of mine is, I am quite sure, perfectly correct.

North again of the Shwe-li are one or two fairly big streams, which join the Salwen north of parallel $26^{\circ}$ or so. (The sources of the Tai-ping and Shwe-li are between $25^{\circ} 38^{\prime}$ and $25^{\circ} 50^{\prime}$ approximately.) The Salwen at that parallel takes a big bend in towards the wcst, and its distance from the Irawadi at about parallel $26^{\circ} 45^{\prime}$ or $27^{\circ}$ I $\epsilon$ stimate cannot bo more than 60 miles as the crow flies. It is very probable that it was at that near approach of these two great rivers that the Chinese mountain tribes came first into contact with the hill tribes of the Irawadi basin, producing the hybrid tribes of Lashis and Azis.

The subject to me is one of intense interest, and, having sojourned up here so many years, I have, of course, had opportunities of theorizing and proving my theories, and the rererse.

H. Hayter Duff.

\section{Earthquakes in Kashgar.}

45, Hornsey Rise Gardens, London, N., September 18, 1902.

I TRA NSMIT to you the following information regarding earthquakes in Kashgar, which I have just received, by a letter cated the 23rd of August last, from my substitute Captain P. J. Miles, British Agent at Kashgar :-

"We have just had a terrible earthquake here. Mr. Petrovski says he has not had a similar experience in these parts. The seismic waves seemed to move from north to south.

"As regards this house, the porch was shaken down, but otherwise no very scrious damage was done. The Russian Consulate too bas suffered a little.

"A good deal of mischief has been done in the town, yamêns, \&c., and there have been some deaths owing to fallings of walls.

"Mr. Petrovski is informing the Russian Gecgraphical Society; and he has kindly given me the following data as to the times of the different shocks :-

" 22nd August.-8 a.m., severe shocks, $1 \frac{1}{2}$ min.; 8.35-9.15, shocks were felt; 915, shocks stronger ; 10, two shocks ; 12 noon, ore shock; 1 p.m., one shock; 
2.30, one shosk; 3 , one shock; and up to 5 p.m. tremblings were felt. The first shock at 8 a.m. caused the main part of the damage.

"Again, last night, between 7.30 p.m. and 9.30 p.m. there were some pretty severe tremblings, an $\mathrm{l}$ there may have bsen others during the night. Fren as I write now at 8 a.m., there has been a shock."

George Macartiey.

\section{GEOGRAPHICAL LITERATURE OF THE MONTH.}

\section{Additions to the Library.}

\section{By EDWARD HEAWOOD, M.A., Librarian, R.G.8.}

The following abbreviations of nouns and the adjectives derived from them are employed to indicate the source of articles from other publications. Geographical names are in each case written in full :-

A. $=$ Academy, Academie, Akademie.

$\mathbf{A} b_{6} .=$ Abhandlungen.

Ann. = Annals, Annales, Annalen.

B. = Bulletin, Bollettino, Boletim.

Com. $=$ Commerce.

O. Rd. = Comptes Rendus.

Erdk. $=$ Erdkunde.

G. = Geography, Geographie, Geografia.

Ges. = Gesellschaft.

I. = Institute, Institution.

Ix. = Izvestiya.

J. = Journal.

k. u. k. = kaiserlich und königlioh.

M. = Mitteilungen.

On account of the ambiguity of the words octavo, quarto, etc., the size of books in the list below is denoted by the length and breadth of the cover in inches to the nearest half-inch. The size of the Journal is $10 \times 6 \frac{1}{2}$.

$\Delta$ selection of the works in this list will be noticed elsewhere in the "Journal."

\section{EUROPE.}

France-Cevennes. B.S. Languedoc. G. 24 (1901): 405-444.

Viala.

La Sérane et ses Mines d’Or. Par M. F. Fernand Viala.

France-Hérault.

Sahuc.

B.S. Languedoc. G. 24 (1901): 67-94, 232-261, 333-348, 488-500.

Sources historiques et bibliographie de l'arrondissement actuel et de l'ancien diocèse de Saint-Pons-de-'Thomières. Par J. Sahuc.

France-Languedoc.

Calvet.

B.S. Languedoc. G. 24 (1901) : 213-231, 316-332, 467-487 ; 25 (1902) : 43-68.

La Montagne noire. Par J. Calvet. Wilh Map and Illustrations.

France-Meteorology. Ann. G. 11 (1902): 203-220. Blanchard. La pluvinsité de la plaine du Nord de la France. Par Raoul Blanchard. With Maps and Diagrams.

Germany-Botany.

Schu'z.

Aug. Schulz: Ueber die Entwicklungsgeschichte der gegenwärtigen phanerogamen Flora und Pflanzendecke Mitteldeutschlands. (Sonderabdruck aus den Berichten der Deutschen Botanischen Gesellschaft, Jahrgang 1902, Band xx. Heft 2.) Berlin, 1902. Size $9 \frac{1}{2} \times 6 \frac{1}{2}$, pp. 54-81. Presented by the Author.

Germany-Nordstrand. Globus 82 (1902) : 31-32.

Hansen.

Die Insel Nordstrand um 1600 . Von R. Hansen.

Based on accounts of the island and its inhabitants written by Pastor Johannes Petersen in the sisteenth century. 